\title{
CaMKII $\beta$ Regulates Oligodendrocyte Maturation and CNS Myelination
}

\author{
Christopher T. Waggener, ${ }^{1}$ Jeffrey L. Dupree, ${ }^{1}$ Ype Elgersma, ${ }^{2}$ and Babette Fuss ${ }^{1}$ \\ ${ }^{1}$ Department of Anatomy and Neurobiology, Virginia Commonwealth University Medical Center, Richmond, Virginia 23298, and ${ }^{2}$ Department of \\ Neuroscience, Erasmus University Medical Center, 3015 GE, Rotterdam, the Netherlands
}

CNS myelination and the maturation of the myelinating cells of the CNS, namely oligodendrocytes, are thought to be regulated by molecular mechanisms controlling the actin cytoskeleton. However, the exact nature of these mechanisms is currently only poorly understood. Here we assessed the role of calcium/calmodulin-dependent kinase type II (CaMKII), in particular CaMKII $\beta$, in oligodendrocyte maturation and CNS myelination. Using in vitro culture studies, our data demonstrate that CaMKII $\beta$ is critical for the proper morphological maturation of differentiating oligodendrocytes, an aspect of oligodendrocyte maturation that is mediated to a large extent by changes in the cellular cytoskeleton. Furthermore, our data provide evidence for an actin-cytoskeleton-stabilizing role of CaMKII $\beta$ in differentiating oligodendrocytes. Using Camk $2 b$ knock-out and Camk $2 b^{\mathrm{A} 303 \mathrm{R}}$ mutant mice, our data revealed an in vivo functional role of CaMKII $\beta$ in regulating myelin thickness that may be mediated by a non-kinase-catalytic activity. Our data point toward a critical role of CaMKII $\beta$ in regulating oligodendrocyte maturation and CNS myelination via an actin-cytoskeleton-regulatory mechanism.

\section{Introduction}

During development, oligodendrocytes, the myelinating cells of the CNS, undergo a lineage progression during which bipolar progenitors give rise to cells with an extended process network that then transition into mature oligodendrocytes, generating the myelin sheath (Pfeiffer et al., 1993; Baumann and Pham-Dinh, 2001). The morphological aspects of this progression are to a large extent regulated by changes in the cellular cytoskeleton (Bauer et al., 2009). However, the exact mechanisms by which the cellular cytoskeleton regulates oligodendrocyte maturation and CNS myelination are currently only poorly understood.

One of the molecular players that emerges as an important regulator of the actin cytoskeleton is calcium/calmodulindependent kinase type II $\beta$ (CaMKII $\beta)$. CaMKII $\beta$ belongs to a family of highly conserved serine/threonine kinases, which in mammals is encoded by four different genes, Camk2a, Camk2b, $C a m k 2 g$, and Camk2d, giving rise to four isozymes, CaMKII $\alpha$, CaMKII $\beta$, CaMKII $\gamma$, and CaMKII $\delta$ (Tombes et al., 2003). Structure-functionally, CaMKII monomers are composed of four domains, a kinase catalytic, an autoinhibitory (regulatory), an

\footnotetext{
Received Dec. 21, 2012; revised April 30, 2013; accepted May 16, 2013.

Author contributions: J.L.D. and B.F. designed research;C.T.W., J.L.D., and Y.E. performed research;C.T.W., J.L.D., and B.F. analyzed data; C.T.W. and B.F. wrote the paper.

This work was supported by the National Institutes of Health-National Institute of Neurological Disorders and Stroke, the National Multiple Sclerosis Society, and the European Leukodystrophies Association. Microscopy was performed at the Virginia Commonwealth University Department of Anatomy and Neurobiology Microscopy Facility, which is supported in part with funding from the National Institutes of Health-National Institute of Neurological Disorders and Stroke Center Core Grant \#5 P30 NS047463. We thank Steve Pfeiffer and Yasunori Hayashi for providing the 04 hybridoma cells and the plasmid encoding GFP-CaMKII $\beta$, respectively, and Robert Tombes for stimulating discussions and critically reading the manuscript.

Correspondence should be addressed to Babette Fuss, Department of Anatomy and Neurobiology, Virginia Commonwealth University, PO Box 980709, Richmond, VA 23298. E-mail: bfuss@vcu.edu.

DOI:10.1523/JNEUROSCI.5875-12.2013

Copyright $\odot 2013$ the authors $\quad 0270-6474 / 13 / 3310453-06 \$ 15.00 / 0$
}

association (oligomerization) domain, and a central variable domain that is subject to alternative splicing and located distal to the autoinhibitory domain (Hudmon and Schulman, 2002). Interestingly, CaMKII $\beta$ has been found to also possess a distinctive actin-binding domain (Okamoto et al., 2009) that has been implicated in mediating actin filament stabilization/bundling (Shen et al., 1998; Fink et al., 2003; O'Leary et al., 2006; Okamoto et al., 2007; Lin and Redmond, 2008). Although primarily characterized in neurons, CaMKII genes, including CaMKII $\beta$, appear to also be expressed by cells of the oligodendrocyte lineage (Cahoy et al., 2008). Therefore, we examined here the role of CaMKII and in particular CaMKII $\beta$ in regulating oligodendrocyte maturation and myelination.

\section{Materials and Methods}

Animals. Sprague Dawley female rats with early postnatal litters were obtained from Harlan Laboratories. Camk $2 b$ knock-out $\left(\right.$ Camk $\left.2 b^{-1-}\right)$ and Camk2 $b^{\mathrm{A} 303 \mathrm{R}}$ mice, both in the F2 129P2-C57BL/6 background (van Woerden et al., 2009; Borgesius et al., 2011), were generated and bred at Erasmus University Medical Center. Animal studies were approved by the institutional animal care and use committee at Virginia Commonwealth University or a Dutch ethical committee for animal experiments.

Primary oligodendrocyte cultures. Primary oligodendrocytes were isolated from postnatal day 3 (P3) rat brains by A2B5 immunopanning (Barres et al., 1992) and then cultured in differentiation medium for at least $48 \mathrm{~h}$ (Lafrenaye and Fuss, 2010). Under these conditions, the majority of cells represented postmigratory, premyelinating oligodendrocytes because they expressed the O4 antigen (Sommer and Schachner, 1982; Warrington et al., 1993; data not shown).

For CaMKII inhibition experiments, cells were cultured for $44-48 \mathrm{~h}$, followed by incubation with: KN-93 or its inactive analog KN-92 (EMD; Millipore), myristoylated autocamtide-2 related inhibitory (Myr-AIP) or myristoylated control (scrambled AIP sequence) peptide (Enzo Life Sciences), or KN93 or KN92 in combination with jasplakinolide (Enzo Life Sciences). 
For siRNA-mediated gene silencing, cells were cultured for 20-24 h and then transfected with siGLO Green transfection indicator along with either an siRNA SMARTpool directed against rat Camk2a, Camk2b, Camk2g, or Camk2d or a control nontargeting siRNA SMARTpool (all from Thermo Fisher Scientific; Lafrenaye and Fuss, 2010).

Oligodendrocyte morphology analysis. Oligodendrocyte morphology was assessed by determining the process index (total area found to be O4-positive minus the area occupied by the cell body) as described previously (Dennis et al., 2008). For the generation of representative images, confocal laser scanning microscopy was used (LSM 510 META NLO; Carl Zeiss). Images represent $2 \mathrm{D}$ maximum projections of stacks of $0.4 \mu \mathrm{m}$ optical sections.

CaMKII $\beta$-F-actin colocalization analysis. Cells of the oligodendroglia cell line CIMO (Bronstein et al., 1998) were nucelofected (Lonza) with a plasmid encoding GFP-CaMKII $\beta$ (Okamoto et al., 2004) and F-actin was visualized using Acti-Stain 555 phalloidin (Cytoskeleton).

PCR and Western blot analysis. For the determination of alternative splicing profiles, end-point RT-PCR analysis was performed using the following gene-specific primer pairs: Camk2a: Forward: 5'-TGGCCACCAGGAACTTCTCCGGAGG-3' and Reverse: 5'TGCGGCAGGACGACGGAGGGCGCCCCAGA-3'); Camk2b: Forward: 5'-CACGGAATTTCTCAGTGGGCAGACAG-3' and Reverse: 5'-CG CAGCTCTCACTGCAGCGGGGCCAC-3'; Camk2g: Forward: 5'CGCTCCGGAAAGGGTGCCATCCTCACAACCATGC-3' and Reverse: 5' ${ }^{\prime}$-TCCGGAGCGTCTCCTCTGACTGACTGGTGCGAGG-3'; and Camk2d: Forward: 5'-CGCTCCGGAACGAGAAATTTTTCAGCAGCCAAGA- ${ }^{\prime}$ and Reverse: 5' $^{\prime}$-TCCGGATCCTGGCTTGATGGGGACTGTT GGGGAC-3'.

For the determination of relative mRNA expression levels, qRT-PCR was performed on a CFX96 Real-Time PCR Detection System (Bio-Rad) using the following gene-specific primer pairs: Camk2a: Forward: 5'ACGGAAGAGTACCAGCTCTTCGAGG-3' and Reverse: $5^{\prime}$-CCTGGCCAGCCAGCACCTTCAC-3'; Camk2b: Forward: 5'-GTCGTCCACAG AGACCTCAAG-3' and Reverse: 5' -CCAGATATCCACTGGTTTGC-3'; Camk2g: Forward: 5'-ACGCAAGTTCAACGCCCGGAGAA-3' and Reverse: 5'-AGGCTCTTGGCAGCTTGCCCG-3'; Camk2d: Forward: 5' TGCCGTCTCTGAAGCACCCCA-3' and Reverse: 5'-ACCAAGTAA TGGAAGCCCTCTTCGG-3'; $M p b$ (exon 2 containing isoforms): Forward: 5'-ACTTGGCCACAGCAAGTACCATGGACC-3' and Reverse: 5'-TTGTACATGTGGCACAGCCCGGGAC-3'; $M p b$ (all isoforms): Forward: 5'-GTGACACCTCGTACACCCCCTCCAT-3' and Reverse: 5'-GCTAAATCTGCTGAGGGACAGGCCT-3'; Plp: Forward: $5^{\prime}$ CCACACTAGTTTCCCTGCTCACCT-3' and Reverse: 5'-GGTGCCTCGGCCCATGAGTT-3'; Cyclophilin (as reference gene): Forward: 5'-GGAGACGAACCTGTAGGACG-3' and Reverse: 5'-GATGCTC TTTCCTCCTGTGC-3'.

For comparing the expression levels of the different Camk2 genes, $R_{0}$ values were determined as described by Peirson et al. (2003). To determine relative expression levels, the $\Delta \Delta C_{\mathrm{T}}$ method was used (Livak and Schmittgen, 2001).

For Western blot analysis, anti-CaMKII $\beta$ (Life Technologies) and anti-GAPDH antibodies (Millipore) were used. Bound antibodies were detected using enhanced chemiluminescence in combination with VersaDoc imaging (Bio-Rad).

Electron microscopic analysis. Spinal cord tissue was prepared and analyzed by electron microscopy as described previously (Dupree et al., 1998; Marcus et al., 2006; Forrest et al., 2009). Numbers of axons were determined manually per field of view $\left(14.6 \mu \mathrm{m}^{2}\right)$. G-ratios were determined as described previously (Dupree et al., 1998; Marcus et al., 2006; Forrest et al., 2009).

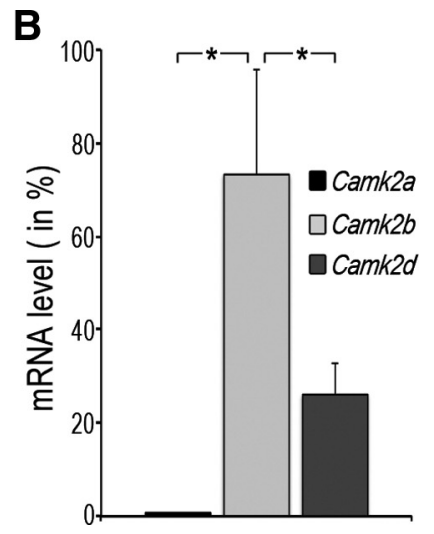

Figure 1. Camk2b is the predominantly expressed Camk2 gene in differentiating oligodendrocytes. $\boldsymbol{A}$, Alternative splicing profile of oligodendrocyte-derived Camk2 genes as determined by end-point RT-PCR analysis. Conserved, nonalternatively spliced "iner" exons within the variable region are depicted as black boxes labeled with the Roman numerals II and VII. Alternatively, PCR analysis. For the bar graph, total Camk2 mRNA levels were set to $100 \%$ and the values for each of the three genes were adjusted accordingly. Data represent means $\pm \operatorname{SEM}\left(n=3\right.$ independent experiments, ${ }^{*} p<0.05$, Student's $t$ test).

\section{Results \\ Camk $2 b$ is the predominant Camk2 gene expressed by differentiating oligodendrocytes}

To determine the extent and alternative splicing pattern of Camk2 gene expression in differentiating oligodendrocytes, endpoint RT-PCR analysis was performed using gene-specific primer pairs spanning the variable domain (Hudmon and Schulman, 2002; Tombes et al., 2003; Fig. 1A). Sequence analysis of the resulting amplification products revealed the expression of Camk2a, Camk2b, and Camk2d, but not Camk2g. All of the three oligodendrocyte-derived genes were found to give rise to multiple alternatively spliced isoforms in a gene-specific fashion. Interestingly, the majority of Camk $2 b$ isoforms contained the alternatively spliced exon I of the variable domain, which has been implicated in conferring actin-binding/stabilizing properties to CaMKII $\beta$ (O'Leary et al., 2006).

To determine the quantitative contribution of each of the three oligodendrocyte-derived Camk2 genes to overall Camk2 expression, qRT-PCR was performed using primer pairs located outside of the variable region and not affected by alternative splicing. This analysis revealed a quantitative expression of Camk2b $>$ Camk2d $>$ Camk2a (Fig. 1B).

\section{Inhibition of CaMKII activity restrains the morphological maturation of differentiating oligodendrocytes}

The above expression analysis suggested that CaMKII, and in particular CaMKII $\beta$, may play an important functional role in differentiating oligodendrocytes. To assess such a potential role of CaMKII, differentiating oligodendrocytes were treated with KN-93, a membrane-permeable pharmacological inhibitor of CaMKII activity, or its inactive derivative KN-92, and process morphology as a measure for oligodendrocyte maturation was determined (Dennis et al., 2008). Treatment with KN-93 caused a decreased process index (Fig. $2 A, B$ ) at $10 \mu \mathrm{M}$ but not $1 \mu \mathrm{M}$. Such concentration dependency is in agreement with a half-maximal inhibition of CaMKII at a KN-93 concentration of $\sim 12 \mu \mathrm{M}$ (Tombes et al., 1995). In addition, cells were treated with the membrane-permeable myristoylated-autocamtide-2-related inhibitory peptide, which mimics the CaMKII autoinhibitory domain (Ishida et al., 1995) and blocks activity at concentrations similar to KN-93 (Easley et 

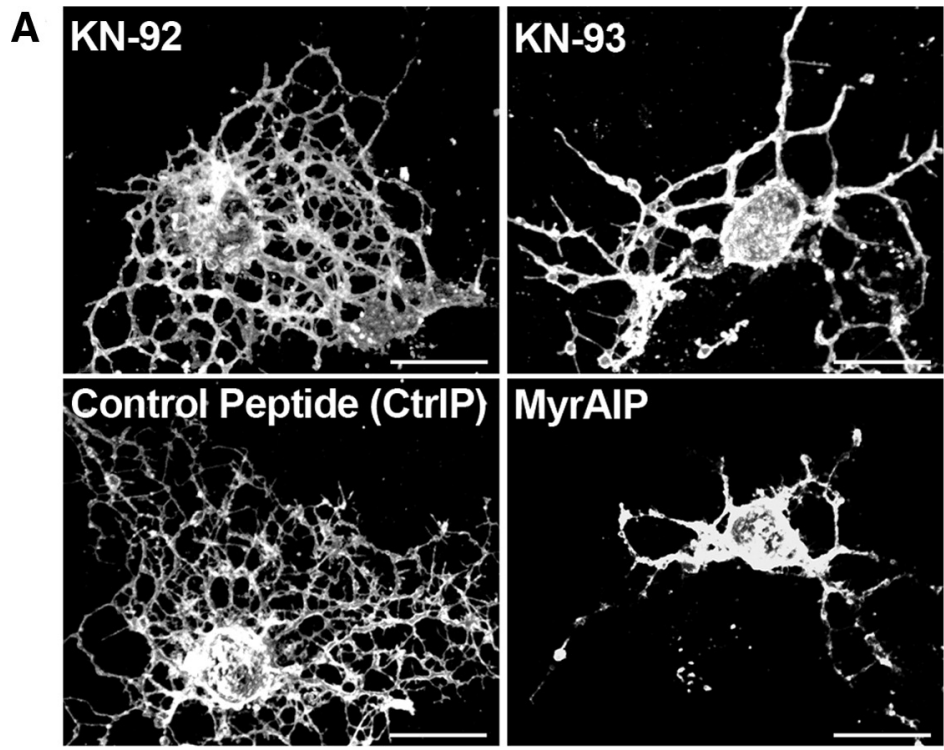

B
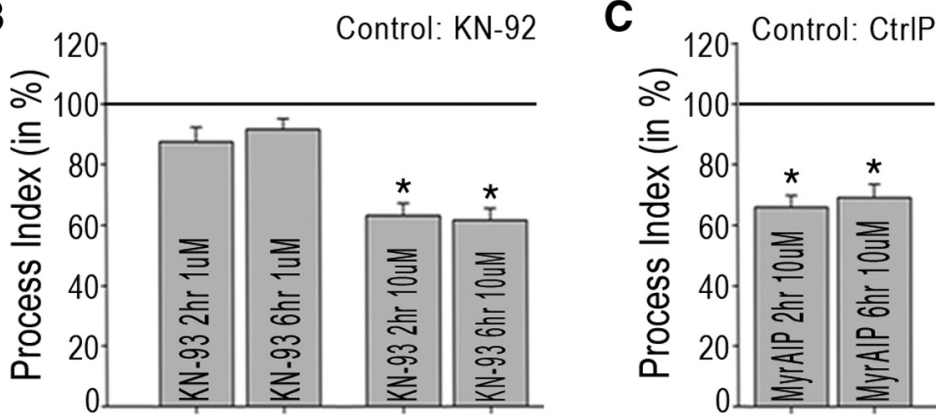

D

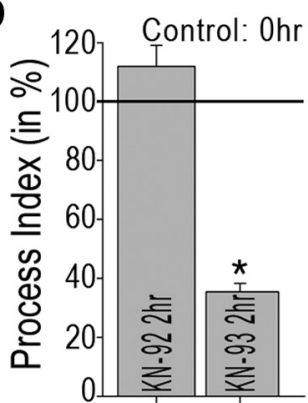

$\mathbf{F}$

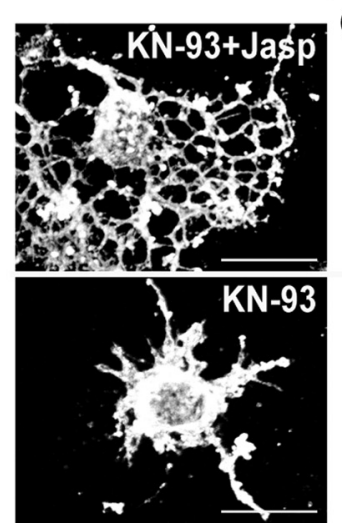

E
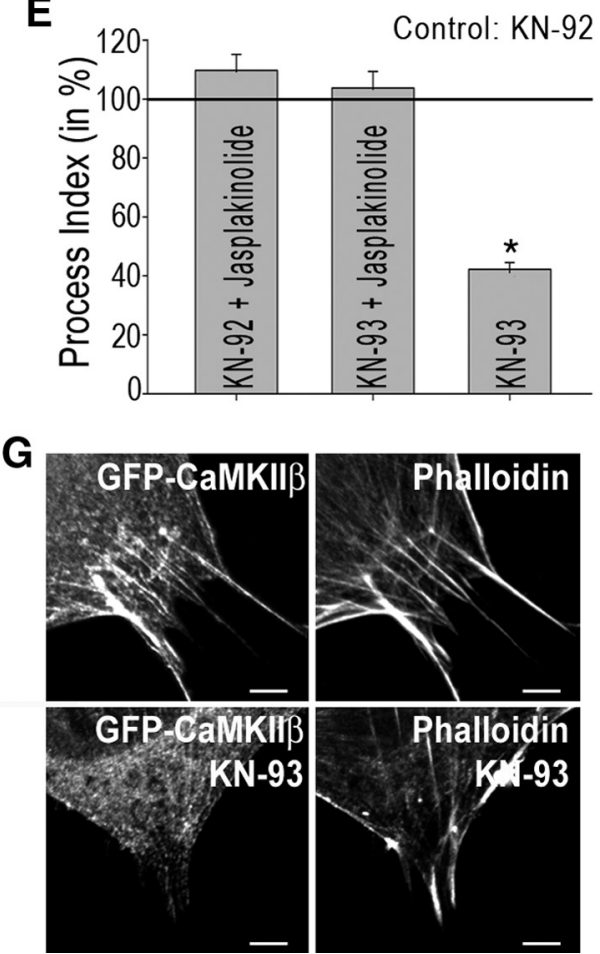

Figure 2. Inhibition of CaMKII activity in differentiating oligodendrocytes restrains the establishment of an expanded process network. $\boldsymbol{A}, \boldsymbol{F}$, Representative images of differentiating oligodendrocytes immunostained with the 04 antibody and treated for $6 \mathrm{~h}$ as indicated. Scale bars, $20 \mu \mathrm{m}$. $\boldsymbol{B}-\boldsymbol{E}$, Bar graphs representing quantitative analyses of process indices as described by Dennis et al. (2008). Cells in $\boldsymbol{B}, \boldsymbol{D}, \boldsymbol{E}$ were treated with the pharmacological CaMKIl inhibitor KN-93 or its inactive derivative KN-92 as control, and al., 2006; Easley et al., 2008). Such treatment resulted similar to the $\mathrm{KN}-93$ treatment in a decreased process index (Fig. 2C). CaMKII inhibition was not found to be associated with a change in cell viability (KN-92: $100 \pm 9 \%$; KN-93: $96 \pm 12 \%)$.

Morphological maturation of oligodendrocytes occurs as a dynamic process that is characterized by process extension and retraction events (Kachar et al., 1986; Fox et al., 2006). As shown in Figure 2D, process indices were found to be significantly decreased $2 \mathrm{~h}$ after initial KN-93 treatment compared with the process indices found at the beginning of the treatment. Therefore, the decreased morphological maturation seen in response to CaMKII inhibition is likely due to an increase in process retraction events rather than an inhibition of process outgrowth.

Retraction of cellular processes has been associated with destabilization of the actin cytoskeleton (Easley et al., 2006). KN-93 has been well described to inhibit not only CaMKII's kinase catalytic activity, but also CaMKII $\beta$ 's actin-binding/ stabilizing activity (Sumi et al., 1991; Lin and Redmond, 2008). Accordingly, a marked reduction in F-actin-CaMKII $\beta$ co-localization was noted upon KN-93 treatment (Fig. 2G). Furthermore, and in support of an actin-destabilizing effect of KN-93 treatment in differentiating oligodendrocytes, cotreatment with jasplakinolide, which specifically and rapidly blocks actin filament disassembly (Boggs and Wang, 2004), abolished the effect of KN-93 on the oligodendrocyte's process network (Fig. 2E,F). No evidence for a change in cellular viability was noted.

cells in C were treated with the myristoylated autoinhibitory CaMKII peptide (Myr-AIP) or a myristoylated control peptide (CtrlP). Cells in $\boldsymbol{E}$ were cotreated with the actin stabilizing peptide jasplakinolide $(10 \mu \mathrm{m})$ where noted and analyzed after $6 \mathrm{~h}$ of treatment. Otherwise, final concentrations and duration of treatments are indicated within the bar graphs. In $\boldsymbol{B}, \boldsymbol{C}, \boldsymbol{E}$, experimental conditions were compared with control-treated cells cultured for an equivalent period of time. In $\boldsymbol{D}$, experimental conditions were compared with control-treated cells at time-point 0 . For all bar graphs, the mean values for control cells were set to 100\% (horizontal gray line) and experimental values were calculated accordingly. At least 25 cells per condition and experiment were analyzed in three independent experiments (i.e., a total of at least 75 cells per condition). Data represent experimental means \pm SEM $\left({ }^{*} p<0.05\right.$, Student'st test). $\mathbf{G}$, Representative images of CIMO cells transfected with a plasmid encoding GFP-CaMKII $\beta$ and stained for F-actin (phalloidin). Scale bars, $5 \mu \mathrm{m}$. 
A

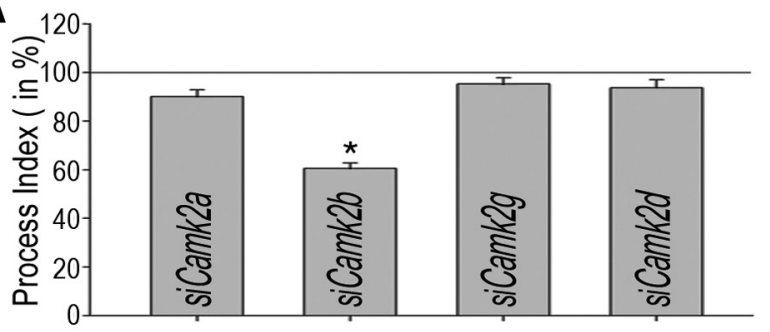

B
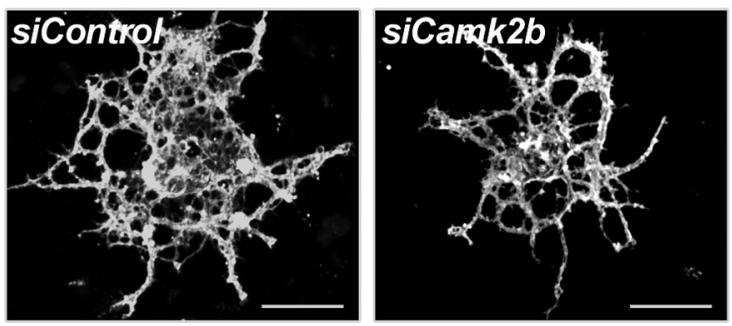

C
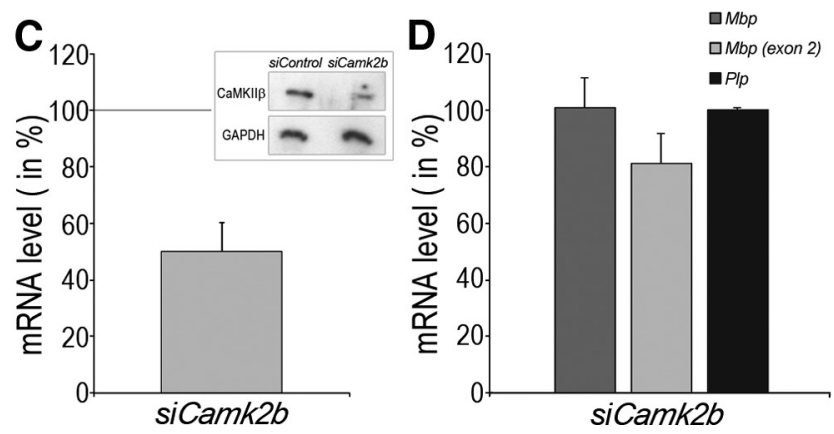

Figure 3. Knock-down of Camk2b expression in differentiating oligodendrocytes restrains the establishment of an expanded process network. $\boldsymbol{A}$, Bar graph representing quantitative analyses of process indices (Dennis et al., 2008) upon siRNA-mediated knock-down of individual Camk2 genes as indicated. The mean value for cells treated with the control siRNA pool was set to $100 \%$ (horizontal gray line) and experimental values were calculated accordingly. At least 25 cells per condition and experiment were analyzed in four independent experiments (i.e., a total of at least 100 cells per condition). Data represent experimental means \pm SEM $\left({ }^{*} p<0.05\right.$, Student's $t$ test). $\boldsymbol{B}$, Representative images of differentiating oligodendrocytes immunostained with the 04 antibody and treated with a control (siControl) or Camk2b-specific (siCamk2b) siRNA pool. Scale bars, $20 \mu \mathrm{m}$. C, Bar graph depicting the Camk $2 b \mathrm{mRNA}$ level upon siRNA-mediated knock-down of Camk2b. The mean value for cells treated with the control siRNA pool was set to $100 \%$ (horizontal gray line) and the experimental value was calculated accordingly. The experimental mean \pm SEM $\left({ }^{*} p<0.05\right.$, one sample $t$ test) is shown. The inset depicts a representative Western blot. CaMKII $\beta$ and GAPDH protein levels are shown for cells treated with a control (siControl) or Camk2b-specific (siCamk2b) siRNA pool. D, Bar graph depicting Mbp (total and exon 2 containing) and PIp mRNA levels upon siRNA-mediated knock-down of Camk2b. The mean value for cells treated with the control siRNA pool was set to $100 \%$ (horizontal gray line) and experimental values were calculated accordingly. Data represent experimental means \pm SEM $\left({ }^{*} p<0.05\right.$, one sample $t$ test).

Downregulation of Camk2b expression restrains the morphological maturation of differentiating oligodendrocytes

To determine the extent to which CaMKII $\beta$ may be involved specifically in regulating the morphology of the oligodendrocyte's process network, an siRNA-mediated gene silencing approach was used. As shown in Figure $3 A, B$, treatment with an siRNA pool to Camk $2 b$ led to a significantly decreased process index. Under the conditions used, siRNA treatment resulted in significantly reduced mRNA levels for Camk2b (Fig. 3C), Camk2a (60 $\pm 4 \%)$, and Camk2d (74 $\pm 9 \%)$. Use of an siRNA pool to Camk2g served as a control because expression of Camk $2 g$ was undetectable in our original analysis (Fig. 1A). For cells
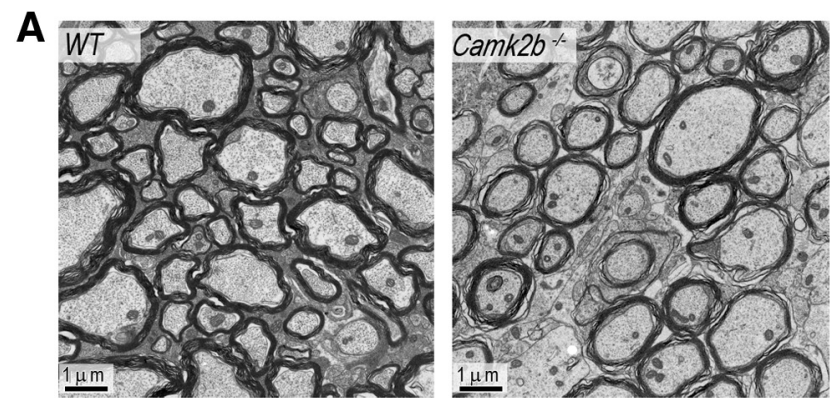

B
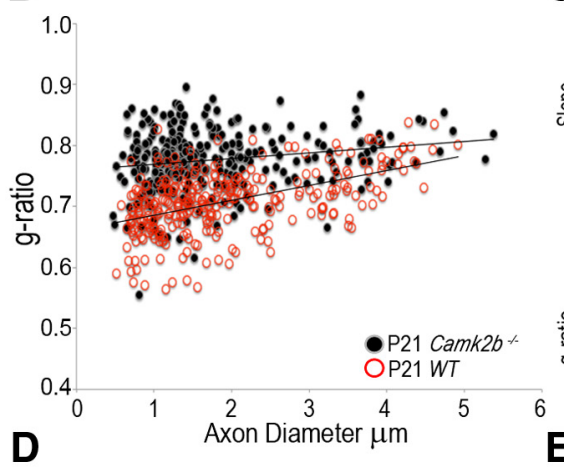

C
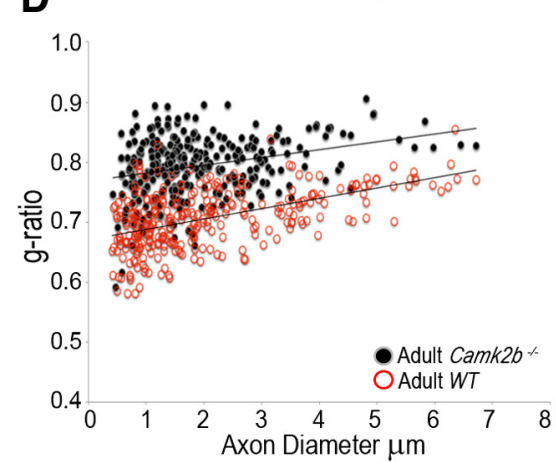

$\mathbf{F}$

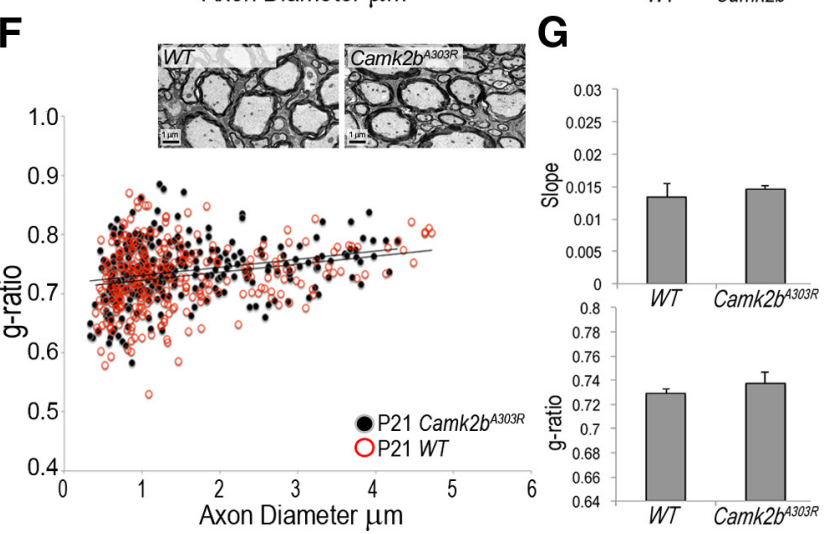

Figure 4. Knock-out of Camk2b leads to an increase in the g-ratio (decrease in the thickness) of the myelin sheath, whereas myelination appears to be unaffected in Camk2 ${ }^{\mathrm{A} 303 \mathrm{R}}$ mutant mice. $\boldsymbol{A}$ and inset in $\boldsymbol{F}$, Representative electron micrographs of the ventral spinal cord of 21-d-old (P21) WT and Camk2b $b^{-/-}$mice in $\boldsymbol{A}$ or Camk2 $2^{\mathrm{A303R}}$ mutant mice in $\boldsymbol{F}$. Scale bars, $1 \mu \mathrm{m} . \boldsymbol{B}, \boldsymbol{D}, \boldsymbol{F}$, Scatter plots depicting g-ratios versus axon diameters for P21 Camk2 $b^{-/-}(\boldsymbol{B})$, adult Camk2 $b^{-/-}(\boldsymbol{D})$, or P21 Camk2 ${ }^{\text {A303R }}(\boldsymbol{F}$; black filled circles) and WT littermate (red open circles) ventral spinal cords. The lines represent linear fits to pooled data from all mice for each genotype. One hundred axons per animal were measured and three animals per genotype were analyzed. C, E, G, Bar graphs depicting average slopes ( $\mathrm{g}$-ratio versus axon diameter) and average $\mathrm{g}$-ratios from individual animals $(n=3)$. Asterisks indicate statistically significant differences between WT and knock-out/mutant mice $\left({ }^{*} p<0.05\right.$, Student's $t$ test). 
treated with the siRNA pool to Camk $2 b$, a reduction in CaMKII $\beta$ protein levels could also be confirmed (Fig. $3 C$, inset). In neither case was the gene-specific downregulation of Camk2 expression associated with an increase in mRNA levels for any of the other Camk2 genes (data not shown).

In vivo, morphological maturation of oligodendrocytes is associated with well described changes in gene expression (Pfeiffer et al., 1993; Baumann and Pham-Dinh, 2001; Emery, 2010). Under experimental conditions, however, molecular mechanisms regulating cellular morphology may be uncoupled from those that regulate gene expression (Osterhout et al., 1999; Buttery and ffrench-Constant, 1999; Kim et al., 2006; Lafrenaye and Fuss, 2010). To investigate a potential role of Camk $2 b$ in regulating gene expression in differentiating oligodendrocytes, expression levels for mRNAs encoding the major myelin genes myelin basic protein $(M b p)$ and proteolipid protein (Plp) (Fulton et al., 2010) were determined. No significant differences were noted (Fig. 3D). In addition, no difference was noted in the percentage of O4positive cells that were also immunopositive for MBP (siControl $52 \pm 4 \%$, siCamk $2 b 49 \pm 2 \%)$.

\section{Systemic knock-out of Camk2b leads to significantly reduced myelination}

To determine the extent to which Camk $2 b$ may regulate developmental myelination in vivo, ventral spinal cords of Camk $2 b^{-1-}$ mice (van Woerden et al., 2009) were analyzed. As shown in Figure $4 A-C$, the myelin sheath g-ratio (axon diameter divided by the diameter of the entire myelinated fiber) was significantly increased at P21 in Camk2 $b^{-1-}$ spinal cords. This effect on myelin thickness persisted up to at least $58 \mathrm{~d}$ of age (Fig. $4 D, E$ ) and was not associated with significant changes in the number of myelinated axons (P21: wild-type [WT] $39 \pm 2 / 14.6 \mu \mathrm{m}^{2}$, Camk2b ${ }^{-1-} 41 \pm 2 / 14.6 \mu \mathrm{m}^{2}$; P58: WT $35 \pm 2 / 14.6 \mu \mathrm{m}^{2}$, Camk $2 b^{-1-} 35 \pm 1 / 14.6 \mu \mathrm{m}^{2}$ ) or apparent signs of axonal damage (Fig. $4 A$ ). In addition, no significant changes in the number of oligodendrocytes were noted (P21: WT $100 \pm 6 \%$, Camk $2 b^{-1-}$ $112 \pm 5 \%)$.

To assess whether the mechanism by which CaMKII $\beta$ regulates oligodendrocyte maturation and CNS myelination may be mediated by a nonenzymatic activity, developmental myelination was assessed in Camk2b ${ }^{\mathrm{A} 303 \mathrm{R}}$ mutant mice. In these mice, the WT Camk $2 b$ gene has been replaced by the mutated Camk2b ${ }^{\mathrm{A} 303 \mathrm{R}}$ gene (Borgesius et al., 2011). This mutation has been characterized to lead to a loss of calcium/calmodulin binding and kinase catalytic activation, but to preserve the ability of CaMKII $\beta$ to bind to and bundle/stabilize actin filaments (Shen and Meyer, 1999; Fink et al., 2003; O'Leary et al., 2006; Lin and Redmond, 2008). As shown in Figure 4, F and G, Camk2b ${ }^{\mathrm{A} 303 \mathrm{R}}$ mutant mice were devoid of the deficits in myelin thickness seen in Camk2b ${ }^{-1-}$ mice.

\section{Discussion}

Using in vitro tissue culture as well as in vivo knock-out and knock-in strategies, we identified CaMKII $\beta$ as a critical component of the molecular mechanism regulating oligodendrocyte maturation and CNS myelination. More specifically, our data point toward a role of CaMKII $\beta$ in regulating the oligodendrocyte's actin cytoskeleton via a mechanism that may not require its kinase catalytic activity, but may instead involve its actin-binding/stabilizing activity.

Our in vivo analysis of developmental myelination demonstrates that CaMKII $\beta$ is involved in the regulation of myelin thickness. Together with our in vitro tissue culture studies, we propose that this regulatory role of CaMKII $\beta$ is at least in part mediated by an oligodendrocyte-autonomous mechanism. In support of this idea, astrocytes are considered to not express considerable levels of Camk2b (Takeuchi et al., 2000; Vallano et al., 2000). In addition, CaMKII $\beta$ protein levels in axons located within the ventral spinal cord have been described to be undetectable or very low (Terashima et al., 1994). Therefore, systemic Camk $2 b$ knock-out is unlikely to cause a predominantly axonmediated effect on myelination within the CNS region investigated here.

The lack of a myelination deficit in the spinal cord of Camk $2 b^{\mathrm{A} 303 \mathrm{R}}$ mutant mice strengthens the idea of a functional role of CaMKII $\beta$ as an actin regulatory protein via its actinbinding activity. In neuronal dendritic spines, CaMKII $\beta$, via its actin-binding activity, is thought to stabilize the actin cytoskeleton and thus overall spine shape. At the same time, however, calcium signaling has been implicated in promoting the release of CaMKII $\beta$ from the actin cytoskeleton, thereby opening a time window during which actin cytoskeleton remodeling events are favored (Okamoto et al., 2007; Okamoto et al., 2009). In analogy, oligodendrocyte maturation and CNS myelination may be regulated by CaMKII $\beta$-mediated alternating cycles of actin cytoskeleton stabilization and destabilization/remodeling. Because CaMKII $\beta$-mediated regulation is dependent on calciumsignaling events, it is worth mentioning that an increase in calcium signaling has been reported to stimulate oligodendrocyte process outgrowth and thus morphological maturation (Yoo et al., 1999). Furthermore, it has been shown recently that balanced activation and deactivation of the actin filament severing and depolymerizing factor cofilin regulates Schwann cell function during peripheral nervous system myelination (Sparrow et al., 2012). This finding supports the idea that efficient myelination may be critically dependent on a well balanced equilibrium between dynamic remodeling and kinetic stability of the actin cytoskeleton. Future studies will be necessary to better define the role of CaMKII $\beta$ in regulating the actin cytoskeleton during oligodendrocyte maturation and CNS myelination.

\section{References}

Barres BA, Hart IK, Coles HS, Burne JF, Voyvodic JT, Richardson WD, Raff MC (1992) Cell death and control of cell survival in the oligodendrocyte lineage. Cell 70:31-46. CrossRef Medline

Bauer NG, Richter-Landsberg C, ffrench-Constant C (2009) Role of the oligodendroglial cytoskeleton in differentiation and myelination. Glia 57: 1691-1705. CrossRef Medline

Baumann N, Pham-Dinh D (2001) Biology of oligodendrocyte and myelin in the mammalian central nervous system. Physiol Rev 81:871-927. Medline

Boggs JM, Wang H (2004) Co-clustering of galactosylceramide and membrane proteins in oligodendrocyte membranes on interaction with polyvalent carbohydrate and prevention by an intact cytoskeleton. J Neurosci Res 76:342-355. CrossRef Medline

Borgesius NZ, van Woerden GM, Buitendijk GH, Keijzer N, Jaarsma D, Hoogenraad CC, Elgersma Y (2011) betaCaMKII plays a nonenzymatic role in hippocampal synaptic plasticity and learning by targeting alphaCaMKII to synapses. J Neurosci 31:10141-10148. CrossRef Medline

Bronstein JM, Hales TG, Tyndale RF, Charles AC (1998) A conditionally immortalized glial cell line that expresses mature myelin proteins and functional GABA(A) receptors. J Neurochem 70:483-491. CrossRef Medline

Buttery PC, ffrench-Constant C (1999) Laminin-2/integrin interactions enhance myelin membrane formation by oligodendrocytes. Mol Cell Neurosci 14:199-212. CrossRef Medline

Cahoy JD, Emery B, Kaushal A, Foo LC, Zamanian JL, Christopherson KS, Xing Y, Lubischer JL, Krieg PA, Krupenko SA, Thompson WJ, Barres BA (2008) A transcriptome database for astrocytes, neurons, and oligoden- 
drocytes: a new resource for understanding brain development and function. J Neurosci 28:264-278. CrossRef Medline

Dennis J, White MA, Forrest AD, Yuelling LM, Nogaroli L, Afshari FS, Fox MA, Fuss B (2008) Phosphodiesterase-Ialpha/autotaxin's MORFO domain regulates oligodendroglial process network formation and focal adhesion organization. Mol Cell Neurosci 37:412-424. CrossRef Medline

Dupree JL, Coetzee T, Suzuki K, Popko B (1998) Myelin abnormalities in mice deficient in galactocerebroside and sulfatide. J Neurocytol 27:649659. CrossRef Medline

Easley CA, Faison MO, Kirsch TL, Lee JA, Seward ME, Tombes RM (2006) Laminin activates CaMK-II to stabilize nascent embryonic axons. Brain Res 1092:59-68. CrossRef Medline

Easley CA 4th, Brown CM, Horwitz AF, Tombes RM (2008) CaMK-II promotes focal adhesion turnover and cell motility by inducing tyrosine dephosphorylation of FAK and paxillin. Cell Motil Cytoskeleton 65:662674. CrossRef Medline

Emery B (2010) Regulation of oligodendrocyte differentiation and myelination. Science 330:779-782. CrossRef Medline

Fink CC, Bayer KU, Myers JW, Ferrell JE Jr, Schulman H, Meyer T (2003) Selective regulation of neurite extension and synapse formation by the beta but not the alpha isoform of CaMKII. Neuron 39:283-297. CrossRef Medline

Forrest AD, Beggs HE, Reichardt LF, Dupree JL, Colello RJ, Fuss B (2009) Focal adhesion kinase (FAK): A regulator of CNS myelination. J Neurosci Res 87:3456-3464. CrossRef Medline

Fox MA, Afshari FS, Alexander JK, Colello RJ, Fuss B (2006) Growth conelike sensorimotor structures are characteristic features of postmigratory, premyelinating oligodendrocytes. Glia 53:563-566. CrossRef Medline

Fulton D, Paez PM, Campagnoni AT (2010) The multiple roles of myelin protein genes during the development of the oligodendrocyte. ASN Neuro 2:e00027. CrossRef Medline

Hudmon A, Schulman H (2002) Structure-function of the multifunctional $\mathrm{Ca}^{2+} /$ calmodulin-dependent protein kinase II. Biochem J 364:593-611. CrossRef Medline

Ishida A, Kameshita I, Okuno S, Kitani T, Fujisawa H (1995) A novel highly specific and potent inhibitor of calmodulin-dependent protein kinase II. Biochem Biophys Res Commun 212:806-812. CrossRef Medline

Kachar B, Behar T, Dubois-Dalcq M (1986) Cell shape and motility of oligodendrocytes cultured without neurons. Cell Tissue Res 244:27-38. Medline

Kim HJ, DiBernardo AB, Sloane JA, Rasband MN, Solomon D, Kosaras B, Kwak SP, Vartanian TK (2006) WAVE1 is required for oligodendrocyte morphogenesis and normal CNS myelination. J Neurosci 26:5849-5859. CrossRef Medline

Lafrenaye AD, Fuss B (2010) Focal adhesion kinase can play unique and opposing roles in regulating the morphology of differentiating oligodendrocytes. J Neurochem 115:269-282. CrossRef Medline

Lin YC, Redmond L (2008) CaMKIIbeta binding to stable F-actin in vivo regulates F-actin filament stability. Proc Natl Acad Sci U S A 105:1 5791-15796. CrossRef Medline

Livak KJ, Schmittgen TD (2001) Analysis of relative gene expression data using real-time quantitative PCR and the 2(-Delta Delta C(T)) Method. Methods 25:402-408. CrossRef Medline

Marcus J, Honigbaum S, Shroff S, Honke K, Rosenbluth J, Dupree JL (2006) Sulfatide is essential for the maintenance of CNS myelin and axon structure. Glia 53:372-381. CrossRef Medline

Okamoto K, Nagai T, Miyawaki A, Hayashi Y (2004) Rapid and persistent modulation of actin dynamics regulates postsynaptic reorganization underlying bidirectional plasticity. Nat Neurosci 7:1104-1112. CrossRef Medline

Okamoto K, Narayanan R, Lee SH, Murata K, Hayashi Y (2007) The role of CaMKII as an F-actin-bundling protein crucial for maintenance of dendritic spine structure. Proc Natl Acad Sci U S A 104:6418-6423. CrossRef Medline
Okamoto K, Bosch M, Hayashi Y (2009) The roles of CaMKII and F-actin in the structural plasticity of dendritic spines: a potential molecular identity of a synaptic tag? Physiology (Bethesda) 24:357-366. CrossRef Medline

O'Leary H, Lasda E, Bayer KU (2006) CaMKIIbeta association with the actin cytoskeleton is regulated by alternative splicing. Mol Biol Cell 17:46564665. CrossRef Medline

Osterhout DJ, Wolven A, Wolf RM, Resh MD, Chao MV (1999) Morphological differentiation of oligodendrocytes requires activation of Fyn tyrosine kinase. J Cell Biol 145:1209-1218. CrossRef Medline

Peirson SN, Butler JN, Foster RG (2003) Experimental validation of novel and conventional approaches to quantitative real-time PCR data analysis. Nucleic Acids Res 31:e73. CrossRef Medline

Pfeiffer SE, Warrington AE, Bansal R (1993) The oligodendrocyte and its many cellular processes. Trends Cell Biol 3:191-197. CrossRef Medline

Shen K, Meyer T (1999) Dynamic control of CaMKII translocation and localization in hippocampal neurons by NMDA receptor stimulation. Science 284:162-166. CrossRef Medline

Shen K, Teruel MN, Subramanian K, Meyer T (1998) CaMKIIbeta functions as an F-actin targeting module that localizes CaMKIIalpha/beta heterooligomers to dendritic spines. Neuron 21:593-606. CrossRef Medline

Sommer I, Schachner M (1982) Cell that are O4 antigen-positive and O1 antigen-negative differentiate into $\mathrm{O} 1$ antigen-positive oligodendrocytes. Neurosci Lett 29:183-188. CrossRef Medline

Sparrow N, Manetti ME, Bott M, Fabianac T, Petrilli A, Bates ML, Bunge MB, Lambert S, Fernandez-Valle C (2012) The actin-severing protein cofilin is downstream of neuregulin signaling and is essential for Schwann cell myelination. J Neurosci 32:5284-5297. CrossRef Medline

Sumi M, Kiuchi K, Ishikawa T, Ishii A, Hagiwara M, Nagatsu T, Hidaka H (1991) The newly synthesized selective $\mathrm{Ca}^{2+} /$ calmodulin dependent protein kinase II inhibitor KN-93 reduces dopamine contents in PC12h cells. Biochem Biophys Res Commun 181:968-975. CrossRef Medline

Takeuchi Y, Yamamoto H, Fukunaga K, Miyakawa T, Miyamoto E (2000) Identification of the isoforms of $\mathrm{Ca}(2+) /$ calmodulin-dependent protein kinase II in rat astrocytes and their subcellular localization. J Neurochem 74:2557-2567. CrossRef Medline

Terashima T, Ochiishi T, Yamauchi T (1994) Immunohistochemical detection of calcium/calmodulin-dependent protein kinase II in the spinal cord of the rat and monkey with special reference to the corticospinal tract. J Comp Neurol 340:469-479. CrossRef Medline

Tombes RM, Grant S, Westin EH, Krystal G (1995) G G $_{1}$ cell cycle arrest and apoptosis are induced in NIH $3 \mathrm{~T} 3$ cells by $\mathrm{KN}-93$, an inhibitor of CaMK-II (the multifunctional $\mathrm{Ca}^{2+} / \mathrm{CaM}$ kinase). Cell Growth Differ 6:1063-1070. Medline

Tombes RM, Faison MO, Turbeville JM (2003) Organization and evolution of multifunctional $\mathrm{Ca}(2+) / \mathrm{CaM}$-dependent protein kinase genes. Gene 322:17-31. CrossRef Medline

Vallano ML, Beaman-Hall CM, Mathur A, Chen Q (2000) Astrocytes express specific variants of CaM KII delta and gamma, but not alpha and beta, that determine their cellular localizations. Glia 30:154-164. CrossRef Medline

van Woerden GM, Hoebeek FE, Gao Z, Nagaraja RY, Hoogenraad CC, Kushner SA, Hansel C, De Zeeuw CI, Elgersma Y (2009) betaCaMKII controls the direction of plasticity at parallel fiber-Purkinje cell synapses. Nat Neurosci 12:823-825. CrossRef Medline

Warrington AE, Barbarese E, Pfeiffer SE (1993) Differential myelinogenic capacity of specific developmental stages of the oligodendrocyte lineage upon transplantation into hypomyelinating hosts. J Neurosci Res 34:113. CrossRef Medline

Yoo AS, Krieger C, Kim SU (1999) Process extension and intracellular $\mathrm{Ca}^{2+}$ in cultured murine oligodendrocytes. Brain Res 827:19-27. CrossRef Medline 